\title{
BEDEVİ ÜMRANDAN HAZERİ ÜMRANA GEÇIŞ: BOŞ ZAMAN KÜLTÜRÜNE BİR BAKIŞ
}

\author{
Serkan POLAT ${ }^{1}$ \\ Semra AKTAŞ POLAT ${ }^{2}$
}

\begin{abstract}
Özet: $\mathrm{Bu}$ çalışmanın amacı, bedevi ve hadari toplumlar temelinde, günümüz boş zaman anlayışını yorumlamaktır. İbni Haldun, ünlü eseri Mukaddime'de medeni ve beşeri değişme ve gelişmeleri, bedevi ümran ve hadari ümran ile tanımlamıştır. Bedevi ümran, tarıma dayalı toplumları, hadari ümran ise lüks üretim ve tüketime dayanan toplumları ifade etmek amacıyla kullanılmaktadır. Boş zaman düşüncesinde yaşanan gelişimi izleyebilmek amacıyla İbni Haldun'un "ümran", "asabiye", "bedevi ümran" ve "hadari ümran" tanımlarından yararlanılmıştır. İbni Haldun'un görüşlerinin tartışıldığı çalışmalar ve boş zaman kavramının ele alındığı bu çalışmada; hadari toplumların, beşinci seviye ihtiyaçlarından olan boş zamanın, günümüz toplumlarındaki kullanımı bakımından, İbni Haldun'un söylemlerinden çok uzaklaşmadığı sonucuna ulaşılmıştır.
\end{abstract}

Anahtar Kelimeler: İbni Haldun, Ümran, Bedevi Ümran, Hadari Ümran, Boş Zaman.

\section{TRANSITION FROM UMRAN BADAWI TO UMRAN HADHARI: A GLANCE AT LEISURE TIME}

\begin{abstract}
The aim of this study is to interpret the contemporary understanding of leisure on the basis of Umran Badawi and Umran Hadhari societies. The changes and developments in civil and human life are defined with Umran Badawi and Umran Hadhari in Ibn Khaldun's famous work Muqaddimah. Umran Badawi is used to express agriculture-based society while Umran Hadhari is used to express the society based on production and consumption of luxury. Ibn Khaldun's "Umran", "Asabiyyah", " Umran Badawi " and " Umran Hadhari " definitions were used in order to monitor progress experienced in leisure time. In this study, it is concluded that the usage of leisure time in today's societies is not so different as Ibn Khaldun's rhetoric, the fifth level of need, on the basis of evaluations in which Ibn Khaldun's ideas are discussed and the concept of leisure time.
\end{abstract}

Keywords: İbn Khaldun, Umran, Umran Badawi, Umran Hadhari, Leisure Time

\footnotetext{
${ }^{1}$ Yrd. Doç. Dr. Düzce Üniversitesi İşletme Fakültesi, (S. yazar), spolatt@gmail.com

${ }^{2}$ Yrd. Doç. Dr. Düzce Üniversitesi İşletme Fakültesi, saktaspolat@gmail.com
} 


\section{Giriş}

İbni Haldun (1332-1406), ünlü eseri Kitab el-iber'i, 1375'te kaleme almaya başlamıştır. Mukaddime, Kitab el-iber'in mukaddimesidir. Eserin, İbn Haldun'un ölümünden çok kısa bir süre öncesine kadar (1405) uzandığı izlenebilmektedir (Hassan, 1973: 113). Mukaddime, İslam tarihi eserlerinde, gelenek haline gelmiş olan tarihe övgü yerine geçen ve yedi kitaptan oluşan, Kitab el-iber'in tamamına giriş olarak yazılmıştır (Hassan, 1973: 114). İbn Haldun, bu eserin ilk başlarında, esas amacının, zamanın Batı İslam dünyasının iki ana halkı olan Arap ve Berberi halklarının tarihini yazmak olduğunu söylemektedir (Arslan, 2009: 1). İbni Haldun, bir anlamda insanların çabalarını, yönetici güçlerin başarı ve başarısızlıklarını yorumlayarak içinde yaşadığı dünyanın hikâyesini anlatmıştır (Messier, 2008: 275).

Toynbee'nin türünün en büyük işi olarak tanımladığı kitabında, henüz hiçbir zaman ve yerde bir zihin tarafından oluşturulmamış tarihsel spekülasyonu açıklayan İbn Haldun, sosyal bilimin babası ve İslam dünyasında pozitif, tarihsel veya gerçek sosyal bilimlerin kurucusu olarak adlandırılır (Stowasser, 1984: 185). İbn Haldun, Darwin'den beş asır önce evrimin belirli özelliklerini tespit etmiştir ${ }^{3}$. Auguste Comte'un sosyolojiyi keşfinden önce kendi kültür bilimini (ilmi ümran) açıklamıştır. Bilime yapmış olduğu bu katkılardan dolayı İbni Haldun, "sosyolojinin babası" olarak tanınmaktadır (Hassan, 2006: 3). İbni Haldun, bilimsel yöntemler kullanarak insan hayatını anlamlandırmaya çalışmış olmasına rağmen, sosyolojiye olan katkıları Comte, Durkheim, Tönnies ve Marx gibi sosyologlara verilen önemin gerisinde kalmıştır (Abdullahi ve Salawu, 2012: 24).

İbni Haldun, ümran biliminin inşacısıdır. Ümran biliminin konusu, yerkürede topluluklar halinde yaşayan insanların sosyal koşulları, durumları ve onların farklı yerlerde bir araya toplanmaları sonucunda oluşan bir uygarlıktır (Kızılçelik, 2011: 19). İbni Haldun, yeni bilim konusunu "insana özgü ümran ve insana özgü toplum" ile açıklıyor (Dursun, 1977: 21). İbni Haldun, toplumsal yaşamı zorunlu sayar ve ekonomiye dayandırır (Dursun, 1977: 22). İbni Haldun, (1) insanların arkadaşlık, dostluk gibi ilişkiler ve temel ihtiyaçların tatmini için bir arada yaşamaya ihtiyaç duyduklarını ve bu ihtiyacın, işbirliğini ortaya çıkardığını, (2) insanların fiziksel çevreden; psikolojik, sosyolojik ve fiziksel olarak etkilendiklerini düşünmektedir (Farid Alatas, 2014: 25).

İbni Haldun'a göre, insanların birlikteliği ve dünyanın bayındırlığı, ümran anlamına gelir (Albayrak, 2010: 9). İbni Haldun'un ümran anlayışı, bugünün sosyal bilimler anlayışına da 1şık tutmaktadır (Amri, 2008: 351). İbni Haldun, biri bedevilere ${ }^{4}$ diğeri hadarilere ${ }^{5}$ has olmak

\footnotetext{
${ }^{3}$ Konuyu açıklığa kavuşturan Uludağ'ın (2004), Mukaddime'nin 1. cildinin tercümesinde 284 ve 285. sayfada 17. dipnotta yaptığı yorum dikkatle okunmalıdır. Bu konuda yanılgılara sebep olmamak için Uludağ’ın açıklamalarının öz hali verilmiştir; "İbn Haldun, oluş ve yaradılış âlemi, madenden başlayarak bitkiler âlemine, sonra da hayvanlar âlemi haline gelmektedir. Bu üç âlemden her birinin son ve bitiş noktası, onu takip eden âlemin ilk ve başlangıç noktasıdır. İki âlem arasındaki geçiş, köprü vazifesi gören bu nevi varlıklar sayesinde mümkün olmaktadır. İnsan nevi ile ondan bir önceki varlık nevi olan hayvanlar arasındaki geçiş de maymun sayesinde mümkün olmaktadır. Maymunlar âlemi, hayvanlar âleminin son ve bitiş, insanlar âleminin ise ilk ve başlangıç noktasını meydana getirir. Her âlemin son ve en yüksek noktasında bulunan bir varlık, tabii olarak onu takip eden âlemin ilk ve en aşağısında bulunan bir varlık haline gelme istidadına sahiptir."

${ }^{4}$ Bedv-bedavet: Zahir olmak, ortaya çıkmak, bir nesnenin ilk önce peyda olan tarafi. Bedavet: Sahrada oturmak, hadar veya hadaretin zıddı. Bedavi, bedevi, ehl-i bedv: Arazide ve kırda ikamet eden, çadır hayatı yaşayan, göçmen, göçebe, konargöçer (İbni Haldun, 2004: 103).

${ }^{5}$ Hadar: belde, belediyelik; Hadari; Beledi, kasabalı; Hadıra: Şehir, belde, kasaba, köy, meskun yer; Hazır: Şehir, kasaba ve köyde oturan, yerleşik hayat süren. Hadaret kelimesi, kültür ve medeniyet manasina da gelir. Bu medeniyet ve kültür, bedevilere has olan medeniyet ve kültürden farklı olduğuna göre, hadarete yerleşik kültür de denilmektedir. Yerleşik hayatı yaşayan her insan ve toplum medeni olmadığı gibi göçebe bir hayat yaşayan her fert de bedevi olmayabilir. Örneğin, çadır hayatının kendine has bir medeniyeti olabilir. Bu medeniyet, mağaralarda, ormanlarda, dağ başlarında ve köylerde yerleşik olarak yaşayan toplumların sahip oldukları medeniyet seviyelerinden daha ileri ve üstün olabilir (İbni Haldun, 2004: 106).
} 
üzere iki tür ümrandan bahsetmektedir. Bedevi ümrandan hadari ümrana geçiş, mağara ve orman hayatından, köşk ve saray hayatına doğru bir gelişme ve ilerleme çizgisi üzerinden seyretmiştir (İbn Haldun, 2004: 114). Bedevilik ve Hadarilik, iki farklı sosyal hayat biçimidir. İbn Haldun, medeni ve beşeri sahalarda görülen değişme ve gelişmeleri, bedevilik ve hadarilik unsuru ile açıklamaya çalışmıştır (İbn Haldun, 2004: 103). "Yaşam tarzlarındaki farklılık" ifadesiyle İbni Haldun, ekonomik faaliyetteki farklılığı anlamakta ve toplumsal yaşamın iki temel yönünü -kırsal ve kentsel- birbirinden ayırmaktadır (Batseva, 1977: 13).

Günümüzde tanıklık ettiğimiz, küreselleşme ve postmodernizm gibi yakıştırmalarla tanımlanan, teknoloji ve sanayinin sorumlu olarak görüldüğü toplumsal yaşam, İbni Haldun'un tanımladığı "hadari yaşam" tarzıdır. Böylesi bir yaşam tarzında, herkes boş zamana sahip olabilecektir (Parker 1981: 330). Bireylerin, kendilerini geliştirmeleri ve yaşam koşullarına entegrasyonu gibi konular, boş zaman değerlendirme aktivitelerine önem veren sağlıklı kentlerin başta gelen sorumluluklarından birisi haline gelmiştir (Tatlıdil, 2009: 320328). Kent yönetimi doğrultusunda insanların, boş zamanlarını değerlendirebilecekleri, açık veya kapalı rekreasyon alanları, tatil mekânları (turizm destinasyonları) ve alışveriş merkezleri gibi tüketim mekânları, halkın, boş zaman tüketimine sunulmuştur.

Hafta tatili ve ücretli izin hakkı gibi uygulamalarla birlikte dinlenme, aile ile birlikte vakit geçirme ve eğlenme gibi unsurlar önem kazanmış, bu ihtiyaçların giderilmesine yönelik uygulamalar ivme kazanmıştır. Boş zamanların verimli bir şekilde geçirilmesinin, insanların günlük yaşam verimliliğini artıracağı düşüncesi ile bu konu, hem insan hem de toplum sağlığının sürekliliğinde önemli hale gelmiş ve otoriteler tarafından, insanların boş zamanlarını nasıl geçirecekleri üzerinde çeşitli kararlar alınıp uygulamaya geçirilmiştir. Yaşanan bu toplumsal dönüşüm süreci vurgulamak amacıyla kaleme alınan çalışmada, sırasıyla Bedevi Ümran ve Hadari Ümran, İ́bni Haldun'a göre ihtiyaçlar ve boş zaman konuları incelenmektedir.

\section{Bedevi Ümran ve Hadari Ümran}

Bedevilik, göçebe bir hayat tarzı değildir ve uygar hayat tarzından önce gelen toplum biçimlerinin tümünü kapsamaktadır (Hassan, 2010: 191). İbni Haldun, bedevilikten hadariliğe geçişin zorunlu olduğunu düşünmektedir (Kızılçelik, 2011: 41). İbni Haldun (2004: 103) bedevi hayatı, aslolan hayat olarak görmüss ve hadari hayatın, sonradan ortaya çıktığını, bedevi hayatın değişmesi ile meydana geldiğini belirtmiştir. Burada vurgulanması gereken nokta, hadari hayatla birlikte bedevi hayatın yok olmadığı, her iki yaşam biçiminin de varlığını devam ettirdiğidir.

Bedevi kültürün üyeleri, tarım ve hayvancılık yolu ile barınma ve yiyecek gibi birincil ihtiyaçlarını karşılarlar. Hadari kültürün üyeleri ise el sanatları ve ticareti benimsemişlerdir. Toplum böylece; bedevi, yarı-göçebe ve hadari (şehirde) yaşayanlar olmak üzere üçe ayrılmıştır. Her üç yaşam biçiminde de geçimi sağlamak ve toplum üyelerinin korunmasını sağlamak amacıyla toplumsal bir yapılanmaya gidilmiştir (Lambton, 2013: 158). Geçimlerini, ağırlıklı olarak hayvancılık yerine tarımsal üretim ile sağlayan bazı bedevi toplumlar, yerleşik veya yarı-yerleşik olarak yaşamlarını sürdürmektedir. Dolayısıyla, bedevilik her zaman göçebe bir yaşam tarzı anlamına gelmemektedir (Uygun, 2008: 12). Medeniyet, şehir hayatı anlamına gelmiştir (Fromherz, 2010: 127). Uygarlık, sadece büyük şehirlerde yaşamak değil, uygarlığın özelliklerine uygun hayat tarzını da sürdürmektir. Böyle bir yaşam ise lüks üretim ve tüketime yönelme, mutlak siyasal iktidara yönelme ve lüks derecede sofistike ilimlerin bilinmesi olarak ifade edilmektedir (Hassan, 1998: 225).

İbni Haldun, toplumların işleyişini "asabiyet” kavramı ile açıklar. Bu kavram, bir toplumu birbirine bağlayan bağı ifade etmektedir (Y1lmaz, 2010: 77). Asabiye veya sosyal uyum, ortak 
bir dil, kültür ve davranış kodları aracılığı ile toplumları birbirine bağlar (Ahmed, 2002: 30). İbni Haldun'un asabiye kavramı, günümüzde kimlik olarak adlandırılan hegomonik dönüşüm ve medeniyetin açıklayıcısıdır (Kalpakian, 2008: 363). Soydaş dayanışması, grup üyeliği, grup bilinci ve aile bağlarına dayalı bir tür sosyalleşme olarak tercüme edilebilecek olan asabiye olgusunu İbni Haldun, aile bağlarına dayandırmıştır (Boukraa, 2008: 322-323).

İbni Haldun, toplumları bir arada tutabilecek ortak değerin, din olduğunu ifade etmiş ve ailenin dönüşümü üzerinde dinin rolünü vurgulamıştır (Yılmaz, 2010: 78). Asabiye, İslam dünyasında kırılma noktasına ulaşmıştır. Ahmed (2002: 31) bunun nedenlerini; yoğun kentleşme, dramatik demografik değişiklikler, nüfus patlaması, Batı'ya gerçekleşen büyük ölçekli göçler, gittikçe büyüyen zengin ve fakir arasındaki uçurum, kötü yönetim ve idarecilerin yolsuzlukları, sınır tanımayan materyalizm, kimlik krizi, yabancı fikir ve imajlara bağlamıştır. Asabiyet, bedevilerin ayırt edici vasıflarından biridir. $\mathrm{Ne}$ var ki asabiyet bedevilerin sahip olduğu tek özellik değildir (Kayapınar, 2006: 97).

İbni Haldun bedevilerin, saflıklarını daha çok koruduklarını, şehirlilerin ise zamanla yozlaşabildiklerini, medeniyetin zirveye ulaşmasıyla birlikte zevâle (yok olmaya) doğru yaklaştığını ve bu çöküşün, dairesel olarak yeniden bir oluşu başlattığını belirtir (Albayrak, 2010: 9). İbni Haldun (2004: 103-104), bedevileri tarif ederken; mağaralarda, ormanlarda, sahrada ve çadırda, yurtlarda, obalarda, köylerde ve daha küçük yerleşim merkezlerinde yaşadıklarından bahsetmiştir.

Bedeviler, kentsel (hadar) yaşamda bulunması mümkün olmayan gerek hayvancılık gerekse çiftçilik için gerekli olan ekini, otlağı ve tarlayı kırsal yaşamda bulabiliyorlar (İbni Haldun, 1977: 293). Bu nedenle bedevilerin, kırsal alanlarda hayatlarını devam ettirmeleri zorunludur. Bedevilerin sosyal hayatları, gereksinimleri ile geçimleri, yardımlaşmaya ve işbölümüne dayanır (Kızılçelik, 2011: 41). Zorunlu gereksinimlerin ötesinde, zenginliğe ve bolluğa erişilmesi bu toplumları, yerleşim merkezlerini kurmaya iter. $\mathrm{Bu}$ aşamada, zorunlu gereksinimlerin ötesindeki olanakları sağlamak için yardımlaşılır. Daha çok yiyecek ve giyecek elde eder, daha güzel kıyafetler giyer, daha gösterişli evler yaparak daha gösterişli yaşam sürerler. Daha uygar ve daha yerleşik duruma geçmek için kasabalar ve kentler kurma yoluna giderler (İbn Haldun, 1977: 294).

"Kent hayatı, medeniyetin (ümran) gelişmesi için bir zarurettir. İnsan, sosyal bir varlıktır ve ihtiyaçlarını karşılayabilmek için başka insanlara ihtiyaç duyar. Böylece insanlar, ihtiyaçlarını karşılamak üzere şehirlerde toplanırlar. Şehir hayatında, nüfusun artmasına bağlı olarak üretim fazlası oluşur. Bu üretim fazlası, sanata ve eğlenceye harcanır. Bu döngü, medeniyetin gelişmesine katkıda bulunur (Yılmaz, 2010: 77)." İhtiyaçlarından fazlasını üreten toplumlar, yiyecek-içecek veya kıyafet tercihlerinde daha değerli ürünlere yönelmiştir. Böylece, arzularına boyun eğen, artan ihtiyaçlarını sağlamak için her türlü yola, kurnazlığa, yalana, dolana ve hilekârlığa başvuran insanların çoğaldığı bir yapı ortaya çıkmıştır (Kızılçelik, 2011: 42-45).

İbni Haldun'a (2004: 106) göre; lüks, konfor, fantezi, bolluk, aşırı üretim ve tüketim, işbölümü, hadari toplumun özellikleridir. Hadari toplum, bedevi toplumun daima önünde ve ilerisinde bulunarak, bedevi toplumu arkasından sürükler. Lüks, gayri meşru yöntemlerle kazanılan zenginliğe neden olurken, ahlaksızlığa da yol açar. İbni Haldun'a göre bu davranışlar, medeniyetin çöküşüne neden olmaktadır (Dhaouadi, 1998: 45). Bedevi toplum, “...Allah'ın kullarını ilk yarattığı hâldedir ve tabiatın insan tarafından bozulmamış/değiştirilmemiş hâli yaşatılmaktadır ve insanın en temel iktisadi faaliyetlerinin olduğu dönemdir (Göcen, 2013: 180).” Bu nedenle İbni Haldun, Mukaddime'de yerleşik hayatın, insan psikolojisi üzerindeki etkilerini gösterirken bu tesirin, olumsuz olduğunu belirtmektedir (K1lıç, 1984: 35). 
Hadarilikle birlikte, toplumsal yapıda çözülme meydana gelmiştir. Lüks ve konfora alışmış olan hadariler; tembelliğe ve maddi menfaatlere yönelmiş, güvenlik problemini siyasi otoriteye havale ederek kendilerine yönelebilecek saldırılara karşı kanunlarla, polis, şehir duvarları ve profesyonel askerlerle kendini koruyabilir hale gelmiştir (Kayapınar, 2006: 98). Böylece gelişmiş güvenlik sistemleri, kent halkının güvenlik kaygılarını azaltmış, insanlar kavgacı özelliğinden vazgeçmiş, silahlarını terk etmiş ve çevreye karşı daha az ilgi duyar hale gelmiş, ayrıca cesaret ve dirençlilik özellikleri yok olmaya başlamıştır (Topses, 2014: 143).

"Bedevi ve Hadari yaşam biçimi, kişilik özelliklerini de etkilemektedir. Öz benlik, ilk doğal aşamasında, kendisine yönelen ve alışkanlık niteliğinde yerleşmek üzere gelen her tür iyi-kötü etkiyi almaya hazırdır. İyiliğe yönelen kişi, iyiliğe ilişkin şeyleri önce edinir ve kötülükten uzaklaşırken, kötülüğe yönelen kişi, kötülüğe ilişkin şeyleri önce edinir ve iyilikten uzaklaşır. Kentliler, çeşitli çekiciliklere, bolluğa-mutluluğa ilişkin şeylerle iç içe bulundukları dünyalığa yöneldikleri ve dünyanın çeşitli tatlarına kendilerini kaptırdıkları için öz benlikleri kirlenmiştir(İbn Haldun, 1977: 298-299)." İbn Haldun bedevileri, hadarilerden daha yiğit, daha mert, hayra ve fazilete daha yakın olduklarını söyleyerek daha üstün kılmıştır. İbni Haldun'a göre, hadarilik ve medenilik, insani fazilet ve meziyetleri az ya da çok zaafa uğratmakta, fitratı değiştirmekte ve tabiiliği bozmaktadır (İbn Haldun, 2004: 105).

\section{İbni Haldun'a Göre İhtiyaçlar}

İbni Haldun'un yaklaşımına göre tüm toplumlar, devletler, şehirler, ekonomiler ve kültürlerin kaçınılmaz bir döngüsel süreci bulunmaktadır. Basit bir şekilde doğan, güçlenen, optimal noktaya ulaşan ve yıpranarak çöküş sürecine giren bir devlet, bu döngü boyunca üç ya da dört nesil varlığını sürdürebilir (Stowasser, 1984: 186). İbni Haldun, devletlerin yükseliş ve çöküş döngüsünü beş aşamada birbirinden ayırır (İbrahim, 1989a: 24-25; Stowasser, 1984: 186187);

Kuruluş aşamasında devleti koruyan akrabalığa dayanan asabiye, ikinci aşamada yerini, hükümdara bırakır ve böylece bir hiyerarşi oluşmuş olur. Üçüncü aşamada hükümdar, otoritesini kullanarak kendi vergi gelirlerini düşürerek gelir elde eder ve elde edilen bu gelir, kamu yararına ve kentin güzelleşmesi için harcanır. El sanatları, güzel sanatlar ve bilim teşvik edilerek geliştirilir. Bu aşama ile birlikte lüks ve konfor, bir alışkanlık haline gelmiştir. Buna bağlı olarak devam eden aşamada devlet, belli belirsiz düşmeye ve parçalanmaya başlamaktadır. Konfor ve lüks alışkanlığı, fiziksel zayıflık ve ahlaksızlık/kötülük üretir. Buna bağlı olarak insanlar, artık uzun süreli planlar yapmaktadırlar. Doğum oranları, düşmektedir. Nüfus, büyük ve kalabalık şehirlerde yaşamakta, hastalıklara ve belalara maruz kalmaktadır. Savurganlık ve israf gelip çatmıştır. Devlet, yaşlanmıştır ve tıpkı fitili bitmiş bir gaz lambası gibi yavaş yavaş ölüme mahkûmdur.

“İbni Haldûn’a göre, toplum hâlinde yaşama zorunluluğunun üç temel sebebi vardır: Gıda, güvenlik ve "üns" yani dostluk ihtiyacı. İnsanlar, bu ihtiyaçlarını, ancak toplumsal hayat yoluyla karşılayabilirler. Bu yüzden toplum hâlinde yaşamaya mecburdurlar. Medeniyet bu üç ihtiyaca cevap verdiği için zorunludur (Şentürk, 2006: 101)." Toplumsal yaşam, İbni Haldun tarafından esas olarak, maddi gereksinimlerle koşullanan insanın, birleşmiş üretici faaliyeti olarak görülür (Batseva, 1977: 12). İnsanın istediği birinci şey, yaşam gereksinimleridir. İnsan, ancak yaşam gereksinimlerine sahip olduğu zaman rahatlığa ve bolluğa erişebilir (Batseva, 1977: 14).

İbni Haldun, ilkel kültürden medeni kültüre doğru geçmek için beş farklı arzunun insanları motive ettiğini ifade etmiştir (İbrahim, 1988). İbni Haldun'a göre, insanların doğuştan gelen ihtiyaçları vardır. İnsan ruhunun arzuları, açlık ve susuzluk gibi basit arzulardan karmaşık 
arzulara kadar uzanabilir (İbrahim, 1989a: 23). İbni Haldun, insanoğlunun ihtiyaçlarını sınıflandırmıştır (İbrahim ve Cordes 2008: 11). Bu sınıflandırmaya göre (İbrahim, 1989a: 24);

Birinci arzu; açlık, susuzluk, 1sınma, serinleme, cinsellik ve üreme gibi bedensel istekleri içerir. İkinci arzu; güvenlik, refah ve huzur arzusudur. Ǘçüncü arzu; ilişki kurma arzusudur. Dördüncü arzu; galip gelme ve servet elde etme arzusudur. Beşinci arzu ise boş zamana yönelik olmak üzere; (1) eğlenme, dinlenme ve gülme, (2) zevk ve haz veren şeyleri duyma, tatma, dokunma, koklama ve görme arzusu ile (3) merak, öğrenme ve bilgi elde etme arzusu olmak üzere üç arzuya yöneliktir.

Eğlence ve beraberindeki faaliyetleri içeren insan arzularının beşinci katmanı, bir toplumun inşası için gerekli olan doğal aşamalardandır. Bu faaliyetlerin eksikliği, devletin yıkımına yol açabilir (İbrahim, 1988). Boş zamanların yükselişi; kişisel rahatlık, kişisel güvenlik ve kişisel hazlar gibi olgulara kapıları açmıştır (Goodman, 1972: 261). İnsanların, lüks ve eğlenceye yönelik eğilimlerinin zamanla artacağını düşünen İbni Haldun, lüks ürünlerin tüketimi ile birlikte beklentilerin de yükseleceğini ifade etmektedir (Spengler, 1964: 303).

Beşinci ve son arzu olarak tanımlanan serbest zaman arzusunu yerine getirmek için Birleşmiş Milletler'in kararlı olduğunu ve pek çok ulusun, bunun için çaba harcadığını ifade eden İbrahim ve Cordes (2008: 11); boş zamanın yükselişi ile birlikte, sivil yaşama ilişkin sorumluluklardan uzaklaşmaya başlanılmasına rağmen, Veblen'in (1953) "aylaklar sınıfı" adlı eserinde bahsettiği anlamı ile boş zamanın, var olma boyutuna, yakın dönemlere kadar ulaşılmadığını ifade etmişlerdir.

\section{Boş Zaman}

1899 y1lında yayınlanan "The Theory of the Leisure Class: An Economic Study in the Evolution of Institutions" adlı eserinde Veblen (1995), bu konuya "aylak sinif" benzetmesi ile yaklaşmış ve daha çok toplumsal statü temelinde değinmiştir. Veblen (1995) insanların, emeklilik içgüdüsü ve gösteriş̧̧i (hasetçi, yarışmacı) eğilim olmak üzere iki temel güdüsünden bahsetmiştir. Aylak sınıfının kurumsallaşmaya geçişini ise ilkel vahşilikten barbarlığa, daha keskin bir deyişle, barışçıl bir yaşam tarzından sürekli savaşa yönelik bir yaşam tarzına geçişle ilişkilendirmiştir (Veblen, 1995: 31).

Torkildsen'in (2005: 11) düşüncesine göre, ilkel topluluklarda boş zaman; geçimini sürdürme, güvenlik ve temel ihtiyaçlara ilişkin baskıların kaldırılmasıyla başlamış ya da firtınalı havalar veya avlardan sonraki bir kutlama şeklinde de ortaya çıkmış olabilir. Boş zaman ya da zorunlulukların olmadığı dönem, bir anlamda, eğlencenin zamanı olarak ifade edilir. Böyle zamanlarda insanlar, eğlenceye normalden daha fazla zaman ayırırlar (Gunter ve Gunter, 1980: 363). Boş zaman, yaşam kalitesi ve iyi oluşu ifade eden yaşam doyumu ile ilişkili bir kavramdir (Hibbins, 1996: 22).

Boş zaman, sadece modern zamanlara ait bir olgu değildir. Doğrudan boş zaman tanımlamasını yapmasa da Aristo, bu konudaki öncü düşünürlerdendir. Aristoteles, insanların, iyi bir yaşam, sağlık ve mutluluğa ulaşmak için bir arayış içinde olduğunu ifade etmiştir (Simpson, 1989: 3). Seneca'ya göre ise insan hayatı, üç evreye ayrılmaktadır. Birinci evre, eğlence ve hazlara; ikinci evre, tefekküre; üçüncü evre ise eylemlere adanmaktadır (İbrahim, 1989c: 18). Juniu (2000: 69-70), Antik Yunan'da doğruluk, iyilik, güzellik ve bilgi gibi yüksek değerler anlamında kullanılan boş zaman anlayışı Roma'da; sosyal statü veya bir yaşam tarzını değil, üretici aktiviteden sonraki bir zamanı ifade etmektedir. Bu bakımdan, Roma anlayışında boş zaman, iş yaşamını desteklemek için bir araç haline gelmiştir. Romalılarda, boş zamanın karşılığı tatil (otium), karşıtıysa iş (negotium) kavramlarıydı (İbrahim, 1989b: 12). 
Konu, dünya nimetleri karşısında umursamazlık içinde olma (Weber, 1997: 35) anlamında kullanılan asketizm (Weber, Protestan ahlak kavramının yerine zaman zaman asketizm deyimini kullanmıştır) ${ }^{6}$ temelinde irdelendiğinde, farklı bir boyut kazanmaktadır. Asketizm, varlıktan doğal zevk alınmasına ve onun hazzını oluşturan şeylere karşıdır. Protestanlık öğretisi olan Püriten anlayışta boş zaman, tembellik ve zaman israfı olarak görülüyordu (Juniu, 2000: 70). Pürüten anlayışta boş zaman; Tanrı'nın şanına değil de insanlarınkine hizmet eden davranışları içeren yalın zevk aracı ya da boş gurur, ham güdü veya usdışı kumar zevkini uyandırınca, doğal olarak kabul görmeyerek insanı, mesleki uğraşıdan uzaklaştırdığ gibi dinden de uzaklaştırdığ düşünülüyordu (Weber, 1997: 147-149). Benzer bir içimde boş zaman, Rousseau'nun da düşmanıdır. Rousseau'nun bu düşüncesinin ardında; kozmopoliten değerlerin küçük bir kasabaya yayılması ile orada, dinin yıkılacağı düşüncesi vardır. Rousseau'ya göre, insanlar çalışmayı, aileyi ve yurttaşlık görevlerini aşan bir üslup edinirlerse moeurs (davranışların, değerlerin ve inançların kesişmesi) yozlaşır (Sennett, 2010: 159-160).

Rojek'in (2004: 51) ifadesine göre boş zaman, iş dışında gönüllü olarak bulunulan etkinliklerde bireylerin, kendilerini yeniledikleri ve özgürce kendilerini geliştirdikleri bir çeşit tamamlayıcı olarak kabul edilen bir zamandır. Haworth (2004: 170), iş ve boş zamanı tanımlamanın zorluğundan ve herhangi bir zaman diliminin, birisi için boş zaman başka birisi için ise çalışma zamanı olabileceğinden bahsetmiştir. Aytaç'ın (2005: 1) ifadesine göre, boş zaman; bireysel dinginlik, düşünsel derinlik ve özgür tercihlerin zamanı değil kapitalizmin, kârı artırmak için ürettiği metaların, kurgusal yaşam deneyimlerinin, alışveriş etkinliklerinin, paket eğlencelerin, medya gösterimlerinin ve kaçışçı eğilimlerin adresi haline geldi.

Boş zamana ilişkin düzenlemeler, 1921'de hafta tatili uygulaması ile başlamıştır denilebilir. Hafta tatili uygulaması, Uluslararası Çalışma Örgütü'nün (ILO) 1921 tarihinde kabul ettiği ve Türkiye'nin de 1946'da onayladığı ILO Sözleşmelerinin, Haftalık Dinlenme (Sanayi) Sözleşmesi kapsamındaki 7. Madde ${ }^{7}$ ile uygulamaya geçmiştir. 1923 yılında gerçekleşen İzmir İktisat Kongresi'nde, tüccar sınıfı, Cuma gününün tatil olmasına ilişkin taleplerini iletmiş (Şahinkaya, 2014: 79) ve 1924 tarihli Hafta Tatili Hakkında Kanun ile hafta tatili Cuma günü olarak gösterilmiş, 1935 tarihli Ulusal Bayram ve Genel Tatiller Hakkında Kanun ile yeniden düzenlenerek hafta tatili Pazar gününe alınmıştır. Bununla birlikte, ilk kez 1925 'te özellikle İngiltere'nin sanayi kentlerinde yaklaşık 1,5 milyon işçi, ücretli izin hakkına kavuşmuş (o dönemde bu haktan yararlananların sayısı 11 milyondur), bu durum ise kalabalık kesimlerin, tatil gereksinimlerini karşılayacak yeni örgütlerin doğumuna neden olmuştur (Eralp, 1983: 16-17).

Birleşmiş Milletler Genel Kurulu'nun 10 Aralık 1948 tarihinde ilan edilen İnsan Hakları Evrensel Beyannamesi'nin 24. Maddesine göre; herkesin dinlenmeye, eğlenmeye, özellikle

\footnotetext{
${ }^{6}$ Weber (1997: 83), asketik Protestanlığın dört tarihi taşıyıcısından bahsetmiştir. (1) 17. yüzyıla işaret eden Kalvenizm, (2) 17. yüzyılın sonlarına işaret eden Pietizm [uyanış ve derin inanç ögütleyen Protestan mezhep (s. 165)], (3) 18. yüzyıla işaret eden Metodizm [sıkı disiplin öngören Protestan mezhep (s. 164)], (4) 17. yüzyılın sonlarına işaret eden Baptist [vaftiz yoluyla arınma temelli Protestan mezhep (s. 162)] hareketten doğan mezhepler. Bu yönü ile asketizm 17. ve 18. yüzyıllara işaret etmektedir.

Bu sözleşme hükümlerinin uygulanmasını kolaylaştırmak için, her patron, müdür veya vekili aşağıdaki mükellefiyetlere tabi olacaktır. Haftalık dinlenme bütün şahıslara toplu bir halde veriliyorsa toplu istirahat gün ve saatlerini, müessese içinde veya başka münasip bir yerde göze çarpacak afişler asmak suretiyle veyahut hükümetçe münasip görülecek diğer herhangi bir şekilde bildirmek, haftalık dinlenme bütün şahıslara toplu bir halde veriliyorsa, memleket kanunlarının veyahut yetkili makamlarca yapılan tüzüğün tarifi dâhilinde hazırlanmış bir deftere hususi bir dinlenme rejimine tabi tutulan işçi veya hizmetlileri ve bu rejimi bildirmek (Türkiye Tarafından Onaylanan ILO Sözleşmeleri, 2014).
} 
çalışma süresinin makul ölçüde sınırlandırılmasına ve belirli tarihlerde ücretli izne çıkmaya hakkı vardır. Bu madde, özellikle ücretli izni (yıllık izin) bir hak konumuna taşımıştır.

Meta haline gelerek doğallığını kaybetmeye başlayan boş zamanın, özel sektör tarafından keşfedilmesi ile birlikte, ekonomik büyümeye yaptığı katkılar, boş zaman endüstrisini ilgi odağına taşımıştır (Hibbins, 1996: 22). Geleneksel toplumdan sanayi toplumuna doğru gerçekleşen dönüşüm sürecinde, insanların karşılaştığı en önemli problemlerden birisi "boş zamanların nasıl değerlendirileceği” konusudur (Kirman, 2005: 20). Boş zamanın metalaştırılması, kapitalizmin ortaya çıkmasında önemli bir rol oynamış, bu anlamda ilk girişimciler; eğlence, spor ve ticari girişimler olarak düzenlenebilecek ve hammaddeye dönüştürülebilecek etkinlikler üzerine odaklanmışlardır (Slater, 2014: 535).

Kapitalizm, boş zaman olgusunun tüketim endüstrisi tarafından ele geçirilmesi ve çalışma dış1 zamanın, değerli bir yaşam alanı olarak görülmeye başlanması ile doğrudan ilişkilidir (Dağtaş ve Dağtaş, 2011: 5). Aytaç (2006: 29), boş zamana dönük bu algisal değişimde, kuşkusuz kapitalizmin yükselişi ve modernitenin büyük rol oynadığını ifade etmiştir. Kapitalizmin de etkisiyle boş zaman, görece, birey kontrolünden çıkmış, adeta "ihtiyaçmış" ve "zorunluymuş" gibi katıldığımız bir etkinlikler alanı haline gelmiştir (Aytaç, 2004: 117).

\section{Sonuç ve Değerlendirme}

İbni Haldun, 1375'ten 1405 'e (Hassan, 1973) kadar uzanan Kitab el-iber'e giriş olarak yazdığı Mukaddime'de, medeni ve beşeri sahalarda görülen değişim ve gelişmeleri (İbn Haldun, 2004) ifade etmek için bedevi ve hadari ümrandan bahsetmiştir. İbni Haldun, bedevi ümrandan hadari ümrana geçişin zorunlu olarak gerçekleştiğini (Kızılçelik, 2011), devletlerin yaşam sürecinin, bunu gerektirdiğini savunmaktadır. İbni Haldun'un tanımladığı bu akış, devletlerin yaşam sürecinde görülen aşamaların, insanların ihtiyaçları doğrultusunda yaşandığını düşündürtmektedir.

İbni Haldun'un beşinci arzu olarak ifade ettiği boş zamana yönelik arzular, lüks ve şatafata düşkünlük, devletlerin sonunu getirmektedir. İbni Haldun gibi püriten anlayış ya da Rousseau'nun düşüncesinde de boş zaman anlayışının, birtakım değerleri tükettiğine ilişkin inanış üzerinde durulmaktadır. Ancak burada dikkat çeken nokta, Rousseau veya Weber (1997) boş zamanın getireceği bazı olumsuzluklar nedeniyle boş zaman anlayışına karşı bir duruş sergilerken, İbni Haldun, böyle bir karşı duruş yerine boş zamana ilişkin isteklerin olduğunu, daha doğrusu -Okumuş’un (2010: 124) zamanı tanımlarken belirttiği gibi- bu durumun toplumsal hayatın kaderi olduğunu düşünmektedir.

İbni Haldun'un bu düşüncesinin üzerinden altı yüz yılı aşkın bir süre geçmiştir. Günümüzde, boş zaman olgusu, Roma anlayışında olduğu gibi iş yaşamını desteklemek amacıyla bir araç (Juniu, 2000) olarak, genel kabul görmüş bir olgu halini almıştır. Günümüzde boş zaman anlayışı, Pürüten anlayışta olduğu gibi insanı, meslek ve dinsellikten uzaklaştırmasının (Weber, 1997) aksine, insanın yaşam kalitesini artıran (Hibbins, 1996), insanı özgürleştiren (Lafargue, 1999), insanı dinginleştiren ve özellikle mesleki uğraşı için bir telafi unsuru halini almıştır.

Günümüzde boş zaman, bir endüstri halini almıştır. İnsanların boş zamanlarının nasıl geçirileceğine yönelik çeşitli kurguların işleyişe konu olduğu boş zaman, bir çalışma alanı oluşturmuştur. Boş zaman endüstrisi, bizlere boş zamanı nasıl geçireceğimize yönelik talimatlar vermekte ve bu, bir boş zamandan öte bir ihtiyaç ve zorunluluk haline dönüşmektedir. Kısacası boş zamanlar, insanın kendi kontrolünden çıkmaya başlamıştır. Böylesi bir oluşumun en önemli nedenleri arasında; sanayileşme, kentleşme, teknolojik gelişmeler ve bunlara bağlı olarak ortaya küreselleşme sayılabilir. 
Günümüzden 600 yıl öncesine uzanan İbni Haldun'un tespitleri, devletlere ilişkin yaşam döngüsünün beşinci evresinde görülen konfor ve lükse düşkünlük, savurganlık ve israfın artış1, nüfusun kentlerde yoğunlaşması, küreselleşme ile birlikte tüm ulus devletlere sirayet etmiştir. Köyden kente doğru yaşanan hareketlilikle birlikte, toprağa olan bağımlılığın azalması, sanayinin gelişmesi ve kadının iş yaşamında varlık göstermesi gibi gelişmelerle birlikte toplumsal yaşam, büyük ölçüde dönüşüme uğramıştır. Toplumsal alanda yaşanan değişim, bedevi yaşam tarzından hadari yaşam tarzına geçiş sürecini hızlandırmıştır. Hadari yaşama uyum sağlayan kent halkı; bilim, sanat, eğitim gibi alanlarla birlikte, lüks ve şatafata eğilim göstermiştir.

Günümüzde insanlar, boş zamanlarını, alışveriş, sinema, tiyatro, spor ve turizm faaliyetleri vb. etkinliklerle geçirme eğilimindedirler. Böylece boş zaman, Debord'un (2010: 129) ifadesinde olduğu gibi eğlence ve tatil anlarının hâkimiyeti altına girmiştir. Boş zaman tüketim mekânları insanlara, iş yaşamının ve sosyal yaşamın kendisine yüklediği rollerden uzaklaşma firsatı sağlar. Bugünün dünyasında boş zaman, İbni Haldun'un beşinci arzu olarak tanımladığ1; eğlenme, dinlenme, gülme, dokunma, koklama, zevk ve hazza yol açan şeyleri görme, merak, öğrenme ve bilgi edinmeye (İbrahim, 1989a) yönelik tüm arzularına cevap verebilen bir endüstri halini almıştır. Ancak İbni Haldun'un devletlere ilişkin tespitlerine dayanarak, hadari yaşam tarzına entegrasyonun bir gereği gibi görülen boş zaman tüketimi, aşırılık, savurganlık, israf lüks ve şatafata dönüşerek bir yaşam tarzı haline geldiğinde, öze ilişkin tüm kodlar ortadan kalktığında, özgün olanın yerini kopyaların doldurması ile geleneksellikten uzaklaşılacak, fiili olarak olmasa da içi boşaltılmış kültürlerin zamanla kaybolması ve kendi özünü yitirmesi kaçınılmaz olacaktır.

\section{Kaynakça}

1. Abdullahi, Ali Arazeem and Salawu, Bashir (2012), "Ibn Khaldun: A Forgotten Sociologist?" South African Review of Sociology, 43 (3): 24-40.

2. Ahmed, Akbar (2002), "Ibn Khaldun's Understanding of Civilizations and the Dilemmas of Islam and the West Today", Middle East Journal, 56 (1): 20-45.

3. Albayrak, Ahmet. (2010), “İbn Haldun'un Medeniyet Tasarımı ve İnsan”, Journal of Islamic Research, 21 (1):7-20.

4. Amri, Loraussi (2008), "The Concept of 'Umran: The Heuristic Knot in Ibn Khaldun", The Journal of North African Studies, 13 (3): 351-361.

5. Arslan, Ahmet (2009), İbni Haldun, 1. Baskı: İstanbul Bilgi Üniversitesi Yayınları.

6. Aytaç, Ömer. (2006), “Tüketimcilik ve Metalaşma Kıskacında Boş Zaman”, Kocaeli Üniversitesi Sosyal Bilimler Enstitüsü Dergisi, 11 (1): 27-53.

7. Aytaç, Ömer. (2005), "Kapitalizm ve Boş Zaman”, Eskişehir Osmangazi Üniversitesi, Sosyal Bilimler Dergisi, 6 (1): 1-22.

8. Aytaç, Ömer. (2004), "Kapitalizm ve Hegemonya İlişkileri Bağlamında Boş Zaman”, C. Ü. Sosyal Bilimler Dergisi, 28 (2): 115-138.

9. Batseva, S. M. (1977), İbni Haldun'un Tarihsel-Felsefi Öğretisinin Toplumsal Temelleri, (çev. Vahap Erdoğdu'dan naklen, Turan Dursun), “Çevirenin Önsözü”, İbn Haldun, Mukaddime, Ankara, 20.

10. Birleşmiş Milletler Genel Kurulu İnsan Hakları Evrensel Beyannamesi (1948), 217 A (III), Resmi Gazete 27 Mayıs 1949, Sayı 7217. 
11. Boukraa, Ridha (2008), "The Khaldunian Concept of 'Umran/Ijtimaa in Light of The Current Paradigm of Post-Modern Society", The Journal of North African Studies, 13 (3): 319-329.

12. Dağtaş, Erdal ve Dağtaş Banu (2011), "Tüketim Kültürü, Yaşam Tarzları, Boş Zamanlar ve Medya Üzerine Bir Literatür Taraması”, Eğitim Bilim Toplum, 4 (14): 4-34.

13. Debord, Guy. (2010), Gösteri Toplumu, (Çev. Ayşen Emekçi ve Okşan Taşkent). 3. Basım. Ayrıntı Yayınları: İstanbul. 55.

14. Devrim Topses, Mehmet (2014), "Ibn Khaldun's Social Structure Analysis", Indian Journal of Applied Research, 4 (3): 140-144.

15. Dhaouadi, Mahmoud (1998), "The Part Ibn Khaldun's Personality Traits and His Social Milieu Played in Shapping His Pioneering Social Thought", İslam Araştırmaları Dergisi, 2: 23-47.

16. Dursun, Turan (1977), "Çevirenin Önsözü", içinde Mukaddime 1 (çev. Turan Dursun). Ankara: Onur Yayınları, 9-45.

17. Eralp, Ziya (1983), Genel Turizm, Ankara Üniversitesi, Basın-Yayın Yüksek Okulu Yayınları: 3.

18. Farid Alatas, Syed (2014), Applying Ibn Khaldūn: The Recovery of a Lost Tradition in Sociology, London and New York: Routledge.

19. Fromherz, Allen James (2010), İbn Khaldun, Life and Times, Edinburgh University Press.

20. Göcen, Gülüşan (2013), “İbn Haldun'un Toplum ve İnsan Yaklaşımının Günümüze Düşen İzdüşümleri: Tüketim Toplumu ve Narsist İnsan”, Toplum Bilimleri Dergisi, 7 (14): 175-198.

21. Goodman, Lenn Evan (1972), "Ibn Khaldun and Thucydides", Journal of the American Oriental Society, 92 (2): 250-270.

22. Gunter, B. G., and Gunter, Nancy C. (1980), "Leisure Styles: A Conceptual Framework for Modern Leisure", The Sociological Quarterly, 21 (3): 361-374.

23. Hafta Tatili Hakkında Kanun (1924), Kanun Numaras1 394, Kabul Tarihi: 2/1/1924, Yayımladığı Resmi Gazete, Tarih: 21/1/1924, Say1: 54.

24. Hassan, Ümit. (1973), “İbn Haldun Mukaddime'si Metninin Yaygınlık Kazanmas1 Üzerine Notlar", Ankara Üniversitesi Siyasal Bilgiler Fakültesi Dergisi, 28 (3): 111-126.

25. Hassan, Ümit (1998), İbn-i Haldun'un Metodu ve Siyaset Teorisi, 2. Bask1: İstanbul: Toplumsal Dönüşüm Yayınları.

26. Hassan, Faridah Hj (2006), "Ibn Khaldun and Jane Addams: The Real Father of Sociology and the Mother of Social Works", Madrid, November, 3 (5).

27. Hassan, Ümit. (2010), İbn-i Haldun'un Metodu ve Siyaset Teorisi, 4. Bask1, Ankara: Doğu Batı Yayınları.

28. Haworth John. T. (2004), "Work, Leisure and Well-Being”, in, (Ed. Haworth John. T. And Veal A.J). Work and Leisure, Routledge. Taylor and Francis Group.Londan and New York. 168-184. 
29. Hibbins, Ray (1996), "Global Leisure”, Social Alternatives, 15 (1): 22-25.

30. İbn Haldun. (2004), Mukaddime 1. (çev. Süleyman Uludağ). Üçüncü Basım, İstanbul: Dergah Yayınlar1.

31. İbni Haldun (1977), Mukaddime I (çev. Turan Dursun). Ankara: Onur Yayınları.

32. İbrahim, Hilmi (1988), “Leisure, idleness and Ibn Khaldun”, Leisure Studies, 7 (1): 51-57.

33. İbrahim, Hilmi (1989a), "Ibn Khaldun 1337-1408”, in, (Ed. Hilmi İbrahim) Pioneers in Leisure and Recreation, American Alliance tor Health, Physic al Education, Recreation, and Dance 1900 Association Drive Reston, VA 22091, pp. 21-26.

34. İbrahim, Hilmi (1989b), "Cicero 106-43 B.C.E”., in, (Ed. Hilmi İbrahim) Pioneers in Leisure and Recreation, American Alliance tor Health, Physic al Education, Recreation, and Dance 1900 Association Drive Reston, VA 22091, pp. 9-13.

35. İbrahim, Hilmi (1989c), "Seneca 4 B.C.E-65 C.E.”, in, (Ed. Hilmi İbrahim) Pioneers in Leisure and Recreation, American Alliance tor Health, Physic al Education, Recreation, and Dance 1900 Association Drive Reston, VA 22091, pp.15-19.

36. İbrahim, Hilmi and Cordes, Kathleen A. (2008), Outdoor Recreation Enrichment For A Lifetime, 3th Edition. Champaign, IL: Sagamore Publishing, L. L. C.

37. Juniu, Susana (2000), “Downshifting: Regaining the Essence of Leisure”, Journal of Leisure Studies, 32 (1): 69-73.

38. Kalpakian, Jack (2008), "Ibn Khaldun's Influence on Current International Relations Theory", The Journal of North African Studies, 13 (3): 363-376.

39. Kayapınar, Akif (2006), “İbn Haldûn'un Asabiyet Kavramı: Siyaset Teorisinde Yeni Bir Açılım”, İsıâm Araştırmaları Dergisi, 15: 83-114.

40. Kılıç, Sadık (1984), Yabancılaşma İnsana Karşı Toplumsal Süreç, İstanbul: Rahmet Yayincilık.

41. Kirman, M. Ali. (2005), "Din ve Eğlence Kültürü KSÜ İlahiyat Fakültesi Öğrencilerinin Mezuniyet Gecesi Hakkında Sosyolojik Bir Değerlendirme”, KSÜ. İlahiyat Fakültesi Dergisi, 6 (2005). 17-42.

42. Kızılçelik, Sezgin. (2011), Sosyoloji Tarihi 1. İbni Haldun, Machiavelli, Montesquieu ve Rousseau'nun Sosyal Teoriler, Genişletilmiş İkinci Baskı. Anı Yayınc1lik: Ankara.

43. Lafargue, Paul (1999), Tembellik Hakkı, (çev. Vedat Günyol). Çağdaş Matbaacılık Yayıncılık Ltd. Şti.

44. Lambton, Ann K. S. (2013), State and Government in Medieval Islam: An Introduction to the Study of Islamic Political Theory: The Jurists. London Oriental Series, Volume 36. London and New York: RoutledgeCurzon, Taylor\&Francis Group.

45. Messier, Ronald A. (2008), “The Worlds of İbn Khaldun: Introduciton", The Journal of North African Studies, 13 (3): 275-277.

46. Okumuş, Ejder (2010), "Zaman Sosyolojisi: Bir Giriş Denemesi”, Din Bilimleri Akademik Araştırma Dergisi, 10 (2): 121-174. 
47. Parker, Stanley. (1981), "Change, Flexibility, Spontaneity, and Self-Determination in Leisure. Social Forces”, Special Issue, 60 (2): 323-331.

48. Rojek, Chris. (2004), "Postmodern Work and Leisure", in. (Ed. Haworth John. T. ve Veal A.J.). Work and Leisure, Routledge. Taylor and Francis Group.Londan and New York. 51-67.

49. Sennett, Richard (2010), Kamusal İnsanın Çöküşü, (çev. Serpil Durak ve Abdullah Yılmaz). 3. Basım. Ayrıntı Yayınları: İstanbul.

50. Simpson, Steven (1989), “Aristotle 384-322 B.C.”, in (Ed. Hilmi İbrahim) Pioneers in Leisure and Recreation, American Alliance tor Health, Physic al Education, Recreation, and Dance 1900 Association Drive Reston, VA 22091, pp.1-8.

51. Slater, Don (2014), "Çalışma/Boş Zaman”, (çev. Şahin Kızılabdullah ve Yıldız Kızılabdullah), içinde, Temel Sosyolojik Dikotomiler, (Ed. Chris Jneks). 2. Baskı. Atıf Yayınları: İstanbul. 528-545.

52. Spengler, Joseph J. (1964), "Economic Thought of Islam: Ibn Khaldun", Comparative Studies in Society and History, 6 (3): 268-306.

53. Stowasser, Barbara (1984), "Ibn Khaldun's Philosophy of History: The Rise and Fall of States and Civillzations", Ankara Üniversitesi SBF Dergisi, 39 (1): 185-190.

54. Şahinkaya, Serdar (2014), Türkiye (İzmir) İktisat Kongresi (17 Şubat-4 Mart 1923). İnönü Vakfi.

55. Şentürk, Recep (2006), "Medeniyetler Sosyolojisi: Neden Çok Medeniyetli Bir Dünya Düzeni İçin Yeniden İbn Haldûn?” İslâm Araştırmaları Dergisi, 16: 89-121.

56. Tatlıdil, Ercan (2009), “Kent ve Kentli Kimliği; İzmir Örneği”, Ege Akademik Bakış, 9 (1): 319-336.

57. Torkildsen, George. (2005), Leisure and Recreation Management, Beşinci Bask1. Taylor and Francis Group.

58. Türkiye Tarafından Onaylanan ILO Sözleşmeleri (2014). Türkiye Tarafından Onaylanan ILO Sözleşmeleri, (Ed. Fazıl Aydın). Çalışma ve Sosyal Güvenlik Bakanlığı. Yayın No: 8.

59. Ulusal Bayram ve Genel Tatiller Hakkında Kanun (1935). Resmi Gazete İlanı: 1/VI/1935-Say1: 3017, No. 2739, Kabul Tarihi: 27 Mayıs 1935.

60. Uygun, Oktay. (2008), İbn-i Haldun'un Toplum ve Devlet Kuramı. Oniki Levha Yayıncılık.1. Bask1: İstanbul.

61. Veblen, Thorstein (1995), Aylak Sınıf, (çev. İnci User). İstanbul: Marmara Üniversitesi Yayın No: 569, İktisadi ve İdari Bilimler Fakültesi Yayın No: 402.

62. Weber, Max. (1997), Protestan Ahlakı ve Kapitalizmin Ruhu, (çev. Zeynep Aruoba). İkinci Baskı. Hil Yayın: İstanbul.

63. Yılmaz, Sinan (2010), "Türk Aile Örüntülerindeki Değişimlerin Açıklanmasında Farklı Sosyoloji Teorilerinin Faydalı Olabilecek Yönleri”, Toplum Bilimleri Dergisi, 4 (8): 67-82. 